\title{
Pemanfaatan eceng gondok untuk menurunkan kandungan biological oxygen demand (BOD), chemical oxygen demand (COD), pH, bau dan warna limbah cair tahu
}

\section{Utilization water hyacinth to reduce biological oxygen demand (BOD), chemical oxygen demand (COD), $\mathrm{pH}$, odor and color of tofu liquid waste}

\author{
Mangoloi Sinurat; Rosmayani Hasibuan; Nelma Hasibuan* \\ 'Jurusan analis kesehatan, Politeknik Kesehatan Medan, Medan-Indonesia \\ *Korespondensi: nelmahasibuan10@gmail.com
}

\begin{abstract}
Di Indonesia terdapat banyak industri tahu mulai dari industri kecil sampai industri besar. Kegiatan industri tersebut menimbulkan limbah yang mengandung zat organik sangat tinggi. Kandungan zat organik dalam limbah cair tahu berpotensi mencemari lingkungan, sehingga perlu adanya pengolahan sebelum dibuang ke lingkungan. Penelitian ini bertujuan untuk mengetahui kemampuan eceng gondok untuk menurunkan kandungan $B O D, C O D$, bau, warna dan meningkatkan $\mathrm{pH}$ yang dilakukan si pabrik pengolahan tahu. Penelitian ini dilaksanakan di pabrik tahu Jalan Ayahanda dan eceng gondok diambil dari sekitar sungai Istana Maimun. Analisis penelitian ini dilakukan di BTKL (Balai Teknik Kesehatan Lingkungan dan Jurusan Analis Poltekkes Medan mulai dari Januari sampai Agustus 2017. Pada penelitian ini digunakan beberapa pengukuran yaitu untuk mengukur kadar BOD dengan DO meter, COD dengan metode open reflow menggunakan $C O D$ reactor tool, $\mathrm{pH}$ dengan $\mathrm{pH}$ meter, bau dan warna dilakukan pengamatan secara fisik. Berdasarkan hasil penelitian yang telah dilakukan, eceng gondok terbukti efektif digunakan untuk menurunkan kadar BOD dan COD, bau, warna serta meningkatkan nilai $\mathrm{pH}$ pada setiap sampel yang digunakan. Semakin banyak eceng gondok yang digunakan maka akan semakin efektif untuk menurunkan ladar BOD, COD, bau, warna, dan meningkatkan nilai $\mathrm{pH}$.
\end{abstract}

Kata kunci: enceng gondok, limbah cair tahu, penyerapan

There are a lot of tofu industries in Indonesia from small to large industries. The industrial activity produces waste. The content of organic substance in the liquid waste potentially pollute the environment, so waste treatment is needed before discharge into the environment. This study aims to determine the ability of water hyacinth to reduce the content of $B O D, C O D$, odor, color and increasing $\mathrm{pH}$ of the tofu that produce in these factory. This research was conducted at the tofu's factory Medan Ayahanda street and water hyacinth are taken around the river Deli Medan Maimon. BTKL (Balai Teknik Kesehatan Lingkungan) and Analis Department Health Polytecnic Medan are where analysis is done from January to August 2017. The method used to measure its value is BOD with DO Meter, COD with open Reflow method using COD Reactor tool, $\mathrm{pH}$ with $\mathrm{pH}$ meter, odor and color in a physical way. Based on the research results, water hyacinth proved effective can be used to reduce BOD and COD levels color, odor and raise $\mathrm{pH}$ on tofu liquid waste twith the same number of samples. Growing number of water hyacinth in the tofu liquid waste, it will be more effective to lower levels of BOD, $C O D$, smell, color and raising $\mathrm{pH}$.

Key words: waste water tofu, water hyacinth, absorption

Industri tahu banyak terdapat di Indonesia. Lokasi industri tahu kebanyakan menyatu dengan pemukiman penduduk, sehingga muncul permasalahan dengan warga sekitar. Industri tahu menghasilkan limbah cair yang dapat mengakibatkan pencemaran terhadap lingkungan. Pencemaran akibat limbah cair tahu dapat berupa: oksigen terlarut rendah, air menjadi kotor, dan bau 
yang menyengat. Menurut Jenie (1995), limbah cair tahu mengandung zat organik yang dapat menyebabkan pesatnya pertumbuhan mikroba dalam air. Hal tersebut akan mengakibatkan kadar oksigen dalam air menurun tajam. Limbah cair tahu mengandung zat tersuspensi, sehingga mengakibatkan air menjadi kotor/keruh. Bahan baku tahu adalah kedelai, asam cuka, dan air. Kandungan protein dalam kedelai dan asam cuka yang ditambahkan dalam proses pembuatan tahu akan menyebabkan limbah cair tahu mengeluarkan bau yang tidak diinginkan.

Bau busuk pada limbah cair tahu disebabkan adanya pemecahan protein yang mengandung sulfur tinggi oleh mikroba alam. Nurtiyani (2000) menyebutkan beberapa dampak dari pencemaran yang diakibatkan oleh adanya industri tahu yaitu: berupa gangguan kehidupan biotik, gangguan kesehatan, gangguan keindahan, serta merusak benda. Eceng gondok merupakan gulma di air karena pertumbuhannya yang begitu cepat. Karena pertumbuhan yang cepat, maka eceng gondok dapat menutupi permukaan air dan menimbulkan masalah pada lingkungan. Selain merugikan karena cepat menutupi permukaan air, eceng gondok ternyata juga bermanfaat karena mampu menyerap zat organik, anorganik serta logam berat lain yang merupakan bahan pencemar. Lumpur aktif juga dapat digunakan untuk mendegradasi zat organik yang terdapat dalam limbah cair tahu.

Pada sistem ini, mikroorganisme akan menguraikan zat organik, sehingga kandungan zat organik dalam limbah cair tahu dapat dikurangi (Widajanti, 2007). Industri tahu merupakan industri rumah tangga dengan modal kecil, sehingga untuk mengolah limbah biasanya pengusaha terbentur oleh biaya yang harus dikeluarkan (Nurtiyani, 2000).

Pada penelitian ini, limbah dari industri tahu terutama limbah cairnya akan diolah dengan menggunakan eceng gondok dan lumpur aktif secara bersama-sama. Penelitian mengenai pengolahan limbah cair tahu secara biologi telah banyak dilakukan Penelitian dengan tujuan untuk mengetahui penurunan $\mathrm{BOD}, \mathrm{COD}, \mathrm{PO}_{4}{ }^{3-}$ (pospat) dan $\mathrm{NH}_{3}$ dalam limbah cair tahu pernah dilakukan oleh Fahri (2002). Pada penelitian ini limbah cair tahu diolah dengan RBC lokal. Hasil penelitian menujukkan bahwa limbah cair tahu setelah dilakukan pengolahan, mengalami penurunan pada variasi waktu tinggal yang berbeda. Berdasarkan uji statistik penurunan terbesar terjadi pada variasi waktu tinggal 6 jam rerata penurunan BOD 89\%, COD $89 \%$, PO4 85\%, dan NH3 25\%. Said dan Herlambang (2006) merancang sistem pengolahan limbah tahu dan tempe dengan proses biofilter anaerob dan aerob. Pengolahan limbah cair tahu dengan proses biofilter anaerob dan aerob, dapat menurunkan konsentrasi COD. Berdasarkan analisis kualitas air limbah tahu sebelum dan sesudah pengolahan, sistem tersebut dapat menurunkan konsentrasi $B O D$ dari $585 \mathrm{mg} / \mathrm{L}$ menjadi $62 \mathrm{mg} / \mathrm{L}$, COD turun dari $1252 \mathrm{mg} / \mathrm{L}$ menjadi $148 \mathrm{mg} / \mathrm{L}$, dan padatan tersuspensi turun dari $429 \mathrm{mg} / \mathrm{L}$ menjadi $26 \mathrm{mg} / \mathrm{L}$. Dengan kombinasi proses biofilter anaerob-aerob didapatkan efisiensi penurunan BOD $89,4 \%$, COD $88,2 \%$ dan SS (Settleable Solids / zat padat terendap ) $94 \%$.

Penelitian mengenai pengolahan limbah cair tahu secara biologi telah banyak dilakukan oleh peneliti-peneliti sebelumnya, akan tetapi memerlukan biaya yang relative mahal, maka penelitian ini akan mencoba untuk mengolah limbah dari industri tahu dengan cara sederhana, murah, dan mudah, yaitu dengan memanfaatkan eceng gondok dalam pengolahan limbah cair tahu yang dihasilkan.

\section{Metode}

Penelitian ini bersifat eksperimen laboratorium yaitu kegiatan percobaan yang bertujuan untuk melihat pengaruh yang ditimbulkan sebagai akibat adanya perlakuan. Rancangan penelitian yang digunakan adalah One Group Pretest-Postest.

Penelitian ini dilakukan di pabrik industri tahu Jalan Ayahanda Medan. Pemeriksaan sampel dilakukan di Balai Teknik Kesehatan Lingkungan Medan (BTKL) dan Jurusan Analis Poltekkes Kemenkes Medan. Penelitian dilaksanakan pada Bulan Januari s/d Agustus 2017. Bahan penelitian yang digunakan adalah limbah cair tahu yang diambil dari pabrik tahu di Jalan Ayahanda Medan. Tanaman eceng gondok diambil dari sekitar sungai Deli Kecamatan Medan Maimon. Tanaman eceng gondok dibersihkan dari kotoran dan tanah yang menempel pada akarnya. Jumlah eceng gondok yang digunakan pada masingmasing perlakuan adalah bervariasi menurut beratnya mulai dari 250 gram, 500 gram, 750 gram, 1000 gram dan 1250 gram berat kering tiris /5 liter limbah cair tahu. Eceng gondok yang digunakan memiliki spesifikasi jumlah daun antara 6-10 lembar, jumlah batang antara 9-15 batang, panjang daun $10-15 \mathrm{~cm}$, lebar daun $8-10 \mathrm{~cm}$ dan tinggi tanaman $20-30 \mathrm{~cm}$.

Parameter yang dianalisis pada penelitian ini antara lain $B O D, C O D$, $p H$, warna dan bau. Analisa BOD Menggunakan Alat dissolved oxygen meter (DO meter), COD dengan methoda Refluks Terbuka, $\mathrm{pH}$ dengan $\mathrm{pH}$ meter warna dan bau dengan metoda fisual. 
Alat yang digunakan adalah 5 buah ember plastik, diameter $30 \mathrm{~cm}$ dan tinggi $50 \mathrm{~cm}$, Jerigen 30 L 10 buah, DO meter, COD Reaktor, Botol winkler, labu erlenmeyer, gelas kimia, gelas ukur, pipet volum, pipet ukur, buret, statif, tabung refluk COD, pipet tetes. Reagensia yang digunakan adalah Larutan Kalium dihidrogen pospat $\left(\mathrm{KH}_{2} \mathrm{PO}_{4}\right)$, Kalium hidropospat $\left(\mathrm{K}_{2} \mathrm{HPO}_{4}\right)$, Natrium hidropospat $\left(\mathrm{Na}_{2} \mathrm{HPO}_{4}\right)$, Ammonium klorida $\left(\mathrm{NH}_{4} \mathrm{Cl}\right)$, Asam klorida $(\mathrm{HCl})$, Natrium hidroksida $(\mathrm{NaOH})$, Magnesium sulfat $\left(\mathrm{MgSO}_{4}\right)$, kalsium klorida $\left(\mathrm{CaCl}_{2}\right)$, Ferri klorida $\mathrm{FeCl}_{3}$, Asam sulfat $\left(\mathrm{H}_{2} \mathrm{SO}_{4}\right)$, Perak sulfat $\left(\mathrm{Ag}_{2} \mathrm{SO}_{4}\right)$,Merkuri sulfat (HgSO4), aquadest.

Aklimatisasi adalah penyesuaian tumbuhan terhadap iklim atau suhu pada lingkungan yang baru dimasuki. Aklimatisasi dilakukan dengan cara menanam eceng gondok pada air bersih selama satu minggu. Pembersihan akar tanaman dilakukan dengan cara menyiramnya dengan air mengalir, dan mengambil tanah yang terjebak dalam akar tanaman.

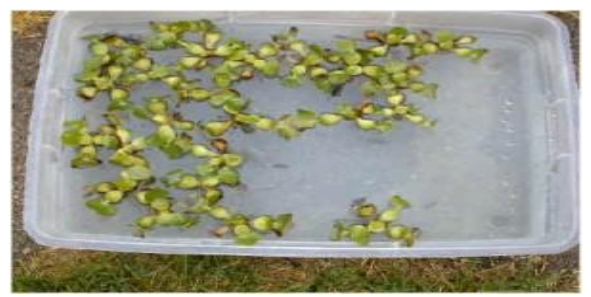

Gbr 1. Media penenaman enceng gondok

Perlakuan terhadap eceng gondok dan analisis parameter. Tanaman eceng gondok dibersihkan dari kotoran dan tanah yang ada pada akarnya, kemudian diaklimatisasi selama satu minggu. Tahap berikutnya adalah mengisi ember dengan limbah cair tahu yang akan ditanami tanaman enceng gondok dengan 5 variasi berat. Sebelum dimasukkan kedalam bak, eceng gondok ditimbang terlebih dahulu untuk mengetahui berat dari eceng gondok. Selanjutnya tanaman eceng gondok ditanam dalam limbah cair tahu. Kemudian diamati perubahan BOD, COD, derajat keasaman $(\mathrm{pH})$, warna dan bau setiap hari selama 5 hari.

Prosedur kerja analisis BOD. Kadar oksigen terlarut sebelum inkubasi. Masukkan sampel cair tahu ke dalam botol winkler sampai penuh dan tutup hingga tidak ada gelembung udara. kemudian masukkan barcode kedalam alat dan celupkan strip kedalam sampel dan baca kadarnya pada alat DO meter.

Kadar oksigen terlarut sesudah inkubasi. Terlebih dahulu disiapkan air pengencer, dimana untuk $1 \mathrm{~L}$ air suling ditambahkan $1 \mathrm{~mL}$ buffer fosfat, $1 \mathrm{~mL}$ larutan $\mathrm{CaCl}_{2}, 1 \mathrm{~mL} \mathrm{MgSO} 4,1 \mathrm{~mL} \mathrm{FeCl}_{3}$.
Campuran tersebut diaerasi dengan aerator selama 30 menit, lalu ditutup. Sampel yang sudah diencerkan dipindahkan ke dalam 2 botol winkler $300 \mathrm{ml}, 1$ botol untuk inkubasi selama 5 hari pada $20^{\circ} \mathrm{C}$, 1 botol lagi untuk ditentukan DO segera $(0$ hari). Air pengencer yang digunakan juga dipindahkan ke dalam 2 botol winkler $300 \mathrm{ml}, 1$ botol untuk inkubasi selama 5 hari pada $20^{\circ} \mathrm{C}, 1$ botol lagi untuk ditentukan DO segera ( 0 hari). Penentuan DO (sama dengan DO sebelum inkubasi).

Prosedur kerja analisis COD. Masukkan 2,0 mL sampel kedalam tabung refluks, tambahkan 1,5 mL larutan digesti dan $3,5 \mathrm{ml}$ reagen sulfat / digesti (campuran $\mathrm{H}_{2} \mathrm{SO}_{4}$ dan $\mathrm{Ag}_{2} \mathrm{SO}_{4}$ ), aduk dan masukkan kedalam COD Reaktor $150^{\circ} \mathrm{C}$ selama 2 jam. Dinginkan dan dan dibaca pada alat pengukur COD.

Prosedur kerja analisis $\mathrm{pH}$. Ambil sampel cair tahu kemudian nyalakan alat $\mathrm{pH}$ meter tersebut dan kemudian celupkan elektroda ke dalam sampel dan tunggu sampai Digital Number pada $\mathrm{pH}$ meter tersebut sampai posisi tidak terubah. Prosedur kerja analisis warna. Masukkan sampel ke dalam gelas kimia dan amati warna secara visual. Prosedur kerja analisis bau. Masukkan sampel ke dalam botol yang permukaannya sempit, kemudian kocok dan tentukan berbau atau tidak. Diagram alur penelitian selengkapnya ditunjukkan pada Gbr 2.

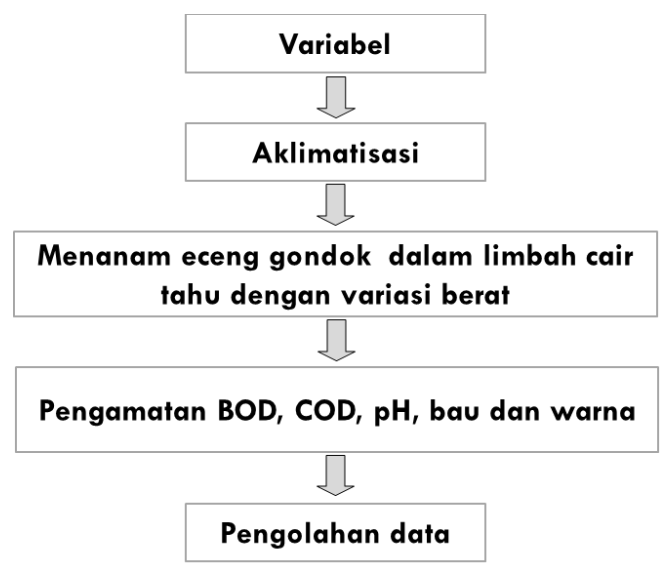

Gbr 2. Diagram alur penelitian

\section{Hasil dan Pembahasan}

Pada awal pengambilan sampel limbah cair tahu sebelum penambahan eceng gondok diperoleh bau yang sangat menyengat. Setelah penambahan eceng gondok, limbah cair dibiarkan selama 5 hari sebelum dilakukan pengamatan dan penentuan kadar. Hari ke 6 merupakan hari pertama pembacaan hasil untuk seluruh 
pemeriksaan, yaitu, Bau, Warna, Kekeruhan, BOD dan COD.

Hasil pengamatan warna limbah cair tahu (Asli) adalah berwarna kuning keruh. Pengamatan warna pada hari pertama setelah penambahan eceng gondok dengan berat 250, 500 dan 750 gram masih menunjukkan warna dan kekeruhan, sedangkan untuk berat eceng gondok 1000 dan 1250 gram sudah tidak berwarna, tetapi masih keruh. Pada hari kedua warna sudah berkurang dan di hari ketiga dst larutan sudah tidak berwarna lagi, akan tetapi larutan masih keruh.

Hasil pemeriksaan $\mathrm{pH}$ dalam air limbah tahu asli adalah 4,3. Hasil pengamatan $\mathrm{pH}$ dari limbah cair tahu sebelum penambahan eceng gondok adalah 4,03, hal ini disebabkan karena asam acetat yang ditambahkan saat proses pembuatan tahu tersebut, sehingga $\mathrm{pH}$ limbahn cair tahu tersebut menjadi asam. Pengamatan $\mathrm{pH}$ pada limbah cair tahu dari seluruh variasi berat eceng gondok yang ditambahkan, rata rata mengalami kenaikan $\mathrm{pH}$ menjadi \pm 6 .

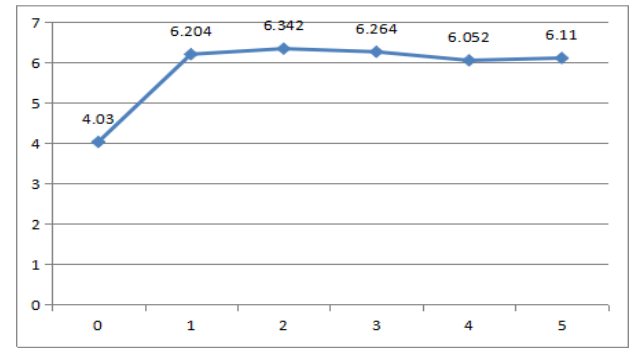

Gbr 3. Grafik pengukuran $\mathrm{pH}$

Hasil pengamatan kadar Biological Oxygen Demand (BOD) dalam air limbah tahu (asli) adalah 229,0 ppm.Dari seluruh variasi berat eceng gondok yang ditambahkan kedalam limbah cair tahu diperoleh penurunan hasil BOD yang signifikan sejak hari pertama pembacaan yaitu sampai angka 118 untuk berat eceng gondok 250 gram dan 37,12 ppm untuk eceng gondok dengan berat 1250 gram dimana makin berat/banyak eceng condok yang ditambahkan semakin besar penurunan kadar BOD dalam limbah tersebut.

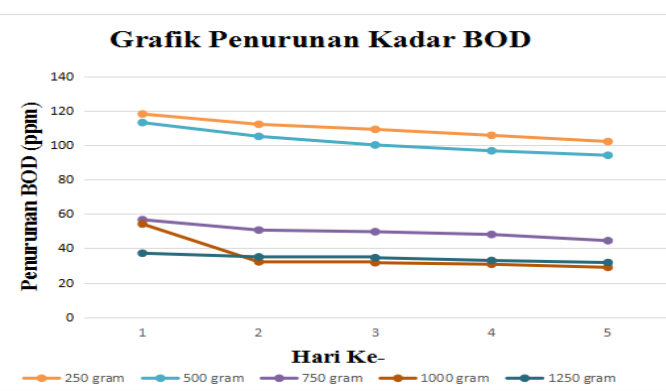

Gbr 4. Grafik pengukuran kadar BOD
Hasil pengamatan kadar chemical oxygen demand (COD) dalam air limbah tahu (asli) adalah 717,0 ppm. Sama halnya dengan pengamatan kadar BOD, penurunan kadar COD juga sesuai dengan berat eceng gondok yang ditambahkan. Makin banyak/berat eceng gondok yang ditambahkan semakin besar penurun angka COD yang diperoleh. Dari seluruh variasi berat eceng gondok yang ditambahkan kedalam limbah cair tahu diperoleh penurunan hasil COD yang signifikan sejak hari pertama pembacaan yaitu sampai angka 370 ppm untuk berat eceng gondok 250 gram dan 116 ppm untuk eceng gondok dengan berat 1250 gram. Demikian juga pada hari ke 2 sampai hari ke 5 terjadi penurunan sampai angka COD 319 ppm untuk penambahan eceng gondok seberat 250 gram, dan 99.00 ppm untuk penambahan eceng gondok sebanyak 1250 gram.

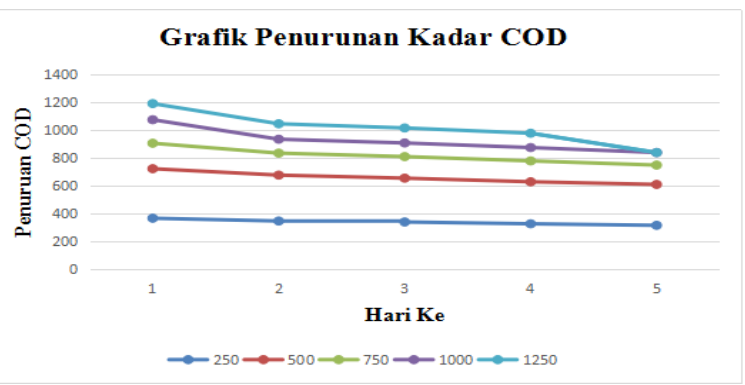

Gbr 5. Grafik hasil penurunan COD

Pada awal pengambilan sampel limbah cair tahu sebelum penambahan eceng gondok diperoleh bau yang sangat menyengat. Bau busuk pada air buangan industri tahu disebabkan adanya proses pemecahan protein yang mengandung sulfur atau sulfat tinggi oleh mikroba alam. Padatan yang terlarut dan tersuspensi dalam air limbah pabrik tahu menyebabkan air keruh. Zat yang menyebabkan air keruh adalah zat organik atau zat-zat tersuspensi dari tahu atau kedelai yang tercecer sehingga air limbah berubah menjadi seperti emulsi keruh. Limbah cair tahu berwarna kuning muda dan disertai adanya suspensi berwarna putih (Purnama, 2007; Yulianti, 2001).

Pada penelitian ini diperoleh hasil yang signifikan terhadap penurunan kadar BOD, COD, bau, warna, dan terhadap kenaikan $\mathrm{pH}$ setelah penambahan eceng gondok pada limbah tahu yang menjadi bahan penelitian. Eceng gondok dapat menyerap zat organik melalui ujung akar. Zat-zat organik yang terserap akan masuk ke dalam batang melalui pembuluh pengangkut kemudian menyebar ke seluruh bagian tanaman eceng gondok. Pada proses ini zat organik akan mengalami reaksi biologi dan terakumulasi di 
dalam batang tanaman, kemudian diteruskan ke daun (Sriyana, 2006).

Pada $\mathrm{pH}$ limbah cair tahu sebelum ditambah eceng gondok adalah 4,3. $\mathrm{pH}$ limbah adalah $\leq$ 4,3 yang menunjukkan bahwa limbah tersebut mengandung asam mineral atau asam organik. Selain itu, gas CO2 yang dihasilkan dari penggunaan zat organik oleh mikroorganisme, dapat berdifusi dengan air membentuk asam karbonat yang bersifat umum (Kasnawati, 2011).

\section{Kesimpulan}

Berdasarkan hasil penelitian yang telah dilakukan, maka dapat ditarik suatu kesimpulan sebagai berikut: (1) Eceng gondok terbukti efektif dapat digunakan untuk menurunkan kadar BOD, COD, $\mathrm{pH}$, bau, warna dan menaikkan $\mathrm{pH}$ pada limbah cair tahu; (2) Berat eceng gondok yang efektif untuk menurunkan kadar BOD, COD, $\mathrm{pH}$, bau, warna dan menaikkan $\mathrm{pH}$ pada limbah cair tahu setelah ditanami selama 5 hari adalah 250 gram/5 liter sampel; dan (3) Semakin banyak eceng gondok yang ditambahkan ke dalam limbah cair tahu maka akan semakin efektif untuk menurunkan BOD, COD, pH, bau, warna. dan menaikkan $\mathrm{pH}$ pada limbah cair tahu tersebut.

\section{Daftar Pustaka}

Anif, S. 1999. Karakteristik limbah cair tahu, permasalahan lingkungan yang ditimbulkan dan upaya penanganannya dikelurahan Mojosonggo Kotamadya dati II Surakarta. Tesis Ilmu Lingkungan, Fakultas Geografi, UGM, Yogyakarta.

Algadrie, Y.S. 2002. kajian kualitas lingkungan yang ditimbulkan limbah cair tahu dan evaluasi sistem unit pengolahan limbah di dusun gerso desa trimurti kecamatan Srandakan Kabupaten Bantul. Tesis, Magister Pengelolaan Lingkungan UGM, Yogyakarta.

Antara, N.Y. 1993. Aklimasi Lumpur Aktif dan Penerapannya dalam Pengolahan Limbah Cair Industri Tahu. Tesis, Ilmu dan Teknologi Pangan UGM, Yogyakarta.

Bahri, S. 2006. Pemanfaatan tumbuhan air (Azzola) untuk pengolahan limbah cair industri tahu di Desa Bandarjaya Kecamatan Terbanggi Besar Lampung Tengah. Fakultas Matematika dan Ilmu Pengetahuan Alam, Universitas Lampung, Lampung.

Damayanti, A., Hermana J. \& Masduqi, A. 2004. Analisis resiko lingkungan dari pengolahan limbah pabrik tahu dengan kayu apu. Jurnal Purifikasi, 5(4):151-156.
Djenar, N.S. \& Budiastuti, H. 2008. Absorpsi polutan amoniak di dalam air tanah dengan memanfaatkan tanaman eceng gondok (Eichhorniacrassipes (Mart) Solm). Spektrum Teknologi, 15(2);97-103.

Fahri, S. 2002. Kandungan biological oxygen demand $(B O D)$, phosphat dan ammoniak limbah cair tahu dengan metoda RBC local. Tesis, Fakultas Kedokteran, Jurusan IImu Kesehatan Kerja UGM, Yogyakarta.

Gerbono, A. \& Siregar, A. 2005. Kerajinan eceng gondok. Kanisius: Yogyakarta.

Hidayat, S. 1993. Peranan eceng gondok (Eirchornia Crassipes mart) dan kangkung air (Ipomoea Aqutica Poir) terhadap peningkatan kualitas air limbah. Tesis, Program Studi Ilmu Tanaman, Jurusan Ilmu-llmu Pertanian, Yogyakarta.

Jenie, B.S.L. 1995. Utilization of tofu and tapioca solid wastes and rise brand to produce red pigments by monascus pupureus in tofu liquid waste medium. Journal Indonesian Food and Nutrision Progress, 2(2):24-29.

Jenie, B.S.L., \& Rahayu, W.P. 1993. Penanganan Limbah Industri Pangan. Kanisius, Yogyakarta.

Junaidi, 2006. Proses pengolahan air limbah secara biologi aerobik; materi pelatihan operator instalasi pengolahan limbah industry. Teknik Lingkungan, Universitas Diponegoro, Semarang.

Kasnawati, 2011 . Penggunaan limbah sabut kelapa sawit sebagai bahan untuk mengolah limbah cair. Diakses Tanggal 8 Februari 2015.

Kristanto, P. 2004. Ekologi industri. Andi Offset, Yogyakarta

Khiatudin, M. 2003. Melestarikan sumber daya air dengan teknologi rawa buatan. Gama Press, Yogyakarta.

Little, L.C. 1979. Handbook of utilization of aquatic plant. FAO Fisheries Technical Paper, No. 187, FAO, Roma.

Mahmud, M.K., Dewi S.S., Rossi, R.A. \& Hermana. 1990. Komposisi zat gizi pangan Indonesia Departemen kesehatan RI. Directorat Bina Gizi Masyarakat dan Pusa Penelitian pengembangan Gizi, Jakarta.

Mickley, H., Sherwood, T.S. \& Reed, C.E. 1975. Applied mathematics in chemical engineering. McGraw-Hill, Inc. New York

Nurtiyani, E. 2000. Mikroalga Chlorella Sp dapat menormalkan limbah tahu. Lembaga Penelitian dan Pengembangan UI, Depok.

Pramudyanto \& Nurhasan. 1991. Penanganan limbah pabrik tahu. Yayasan Bina Lestari, Semarang .

Repley B.S., Muller, E. \& Behenna, M. 2006. Biomass and photosynthetic productyvity of 
water hyacinth as effected by nutrient supply and mirid biocontrol. Biological Control, 39:392-400.

Suprapti, L. 2005. Pembuatan tahu. Teknologi Pengolahan Pangan, Kanisius, Yogyakarta.
Siregar, S.A. 2005. Instalasi pengolahan air limbah. Kanisius, Yogyakarta.

Yulianti, W. 2001. Kemampuan eceng gondok sebagai biofilter zat tersuspensi pada konsentrasi efektif limbah cair tahu. Jurnal Habitat, 23-25. 